Cuadernos de Fllología Clásica. Estudios griegos e indoeuropeos 


\title{
El oráculo griego en la época de la producibilidad escrita: la crisis de la autoridad mántica en Aves (960-996) de Aristófanes
}

\author{
Tomás BARTOLETTI \\ Universidad de Buenos Aires \\ Humboldt-Universität zu Berlin \\ tomasjbarto@gmail.com
}

Recibido: 30-11-2015

Aceptado: 11-12-2015

\section{RESUMEN}

Este artículo se propone analizar la escena del cresmólogo intruso en Aves, revalorizando la comedia aristofánica como fuente de conocimiento histórico. Este análisis se centra en la práctica oracular como una técnica de producción escrita vinculada a la autoridad religiosa. De esta manera, se exploran dos campos de estudios, como la comedia antigua y la adivinación griega, cuyo vínculo no ha sido explorado en profundidad. Para dar cuenta del momento crítico de la institución oracular durante la Guerra del Peloponeso, se reconstruyen perspectivas sobre dicho fenómeno en otras fuentes como Tucídides o Demóstenes. Esto no solo ofrece una mirada «cómica» sobre la adivinación, sino que también permite comprender la práctica oracular como técnica y, en consecuencia, qué elementos de su funcionamiento podían ser manipulados.

Palabras claves: Aristófanes, oráculo, escritura.

\begin{abstract}
The purpose of this paper is to analyze the intruder chresmologe's scene by Birds (960-996), reconsidering the worth of Old Comedy as a source for historical inquiry. This interpretation understands the oracular practice as as a sociotechnical one based on religious authority. To achieve this aim, two fields, like Old Comedy and Greek divination, are interpreted together, a link not usually developed in Classical Studies. The result of this approach witness some aspects of the critical situation that the oracular institution evolved during the Peloponnesian War. Reconstructing other perspectives about the same phenomena from authors like Thucydides or Demosthenes, this article not only explains the «comic» representation of divination, but also focuses on its relevance to consider the oracular practice as a specific technology.
\end{abstract}

\section{ÍNDICE}

1. Introducción. 2. «Lo político» y «lo histórico» en la comedia aristofánica. 2.1. La fundación de la interpretación sociológica. 2.2. La dimensión performática: metateatro como crítica social. 3. El oráculo de Delfos durante la Guerra del Peloponeso. 3.1. Las esperanzas claras por las oscuras: la adivinación según Tucídides. 3.2. Vete a «cresmologuear» con los biblioi a otra parte. 4. Oralidad y escritura de los oráculos griegos. 4.1. Monopolio del saber mántico. 4.2. El oráculo en la oratoria ateniense. 5. Conclusión. 


\section{INTRODUCCIÓN}

La Guerra del Peloponeso fue un hito en el desarrollo del oráculo de Delfos. Testimonio de ello da Tucídides de manera explícita, aunque también pueden extraerse de la comedia de Aristófanes, especialmente de Aves, elementos que permitan explicar la crisis de su autoridad mántica. Siguiendo la propuesta histórico-sociológica fundante de Ehrenberg (1943) y la clave metateatral de Slater (2002), el análisis de la escena del cresmólogo intruso en Aves nos permitiría comprender la dimensión socio-técnica de la práctica oracular y el proceso de inflación de su autoridad mántica. Para ello, será preciso primero señalar la mirada que ofrece Tucídides sobre la crisis de legitimidad sufrida por el oráculo délfico en el contexto de la Guerra del Peloponeso para luego contrastarlo con el «reflejo» de las prácticas adivinatorias y la «atmósfera» respecto de su funcionamiento que ofrece la comedia aristofánica. A través de la lectura de Tucídides, se puede identificar y describir este fenómeno, pero no explicarlo. Es decir, obtenemos un explanadum sobre la crisis de la autoridad mántica en el contexto de la Guerra del Peloponeso, ${ }^{1}$ pero no su explanans. A partir del análisis filológico en clave socio-técnica de las prácticas mánticas que aparecen en la obra de Aristófanes, podríamos aproximarnos, en efecto, a su explanans. ${ }^{2}$ Este consistiría en analizar el funcionamiento socio-técnico del oráculo, en especial la transformación tecnológica que

${ }^{1}$ Tal como señala Gil (1996: 93-94), Aristófanes representa en sus comedias el momento crítico de las creencias religiosas en la Atenas clásica a fines del siglo v a.C.. Este momento se produce por la transición de viejas creencias a nuevos cultos y entre los sectores «ilustrados» y aquellos populares. En particular, se destacan los procesos de asébeia y el auge de la adivinación en las campañas militares, las asambleas y los consejos. La mención o aparición de personajes como Nicias, Lampón y Diopites muestran a las claras el reconocimiento de esta situación. Testimonio similar de este movimiento "ateísta» se puede identificar también en Cinesias, Tucídides y Diágoras de Melo.

${ }^{2}$ Las primeras reflexiones sobre la relación entre técnica y sociedad bien podrían remontarse a mediados del siglo XIX. Nathan Rosenberg (1982) observa en la obra de Karl Marx un punto de inflexión en la forma de estudiar los desarrollos tecnológicos. Si la forma tradicional se enfocaba en la figura del inventor singular y su «genio», Marx propone un abordaje social de la tecnología centrándose en el desarrollo tecnológico como un elemento constitutivo de la explicación histórica. Esta hipótesis puede resumirse en una famosa cita: «El molino trajo la sociedad con señor feudal; la máquina de vapor la sociedad con industrial capitalista» (Miseria de la Filosofía). De esta frase surgieron dos tradiciones que problematizaron la relación entre tecnología y sociedad, planteando dos líneas monocausales deterministas: a) causalidad tecnológica: los cambios tecnológicos (inventos, nuevos productos, nuevos procesos productivos, etc.) determinan cambios sociales; b) causalidad social: los cambios tecnológicos son explicados mediante causas sociales. Recientes estudios sociales de la tecnología y sociología del conocimiento proponen una serie de nuevos abordajes que intentan superar estas limitaciones y contradicciones de los abordajes mono-deterministas. Entre ellos, se destacan la Sociología del Conocimiento Científico y el Programa de la Escuela de Bath, cuyos fundamentos se resumen en, por un lado, la imposibilidad de realizar distinciones a priori entre 'lo tecnológico', 'lo social', 'lo económico' y 'lo científico' y, por el otro, la necesidad de abrir la «caja negra» del conocimiento tecnológico. Con la metáfora del 'tejido sin costuras' (seamless web) se describe el aporte teórico de estas perspectivas. De esta manera, por análisis «socio-técnico» se apunta a comprender el carácter social de la tecnología y el carácter tecnológico de la sociedad. Ver Bijker (1990), White (1990) Marx \& Smith (1996), Thomas (2000). 
generó la posibilidad de su producción escrita en una cultura oral, ${ }^{3}$ es decir, la novedad de su «re-producibilidad» escrita. ${ }^{4}$ Con este fin, se trazará una trayectoria que va del episodio de Onomácrito y los oráculos de Museo narrado por Herodoto (VII.6.3.) hasta el empleo que hace Demóstenes en la oratoria (Sobre la embajada fraudulenta, Contra Macártato). De esta manera, el testimonio de Aristófanes se encuentra en un punto intermedio, que, como se intentará mostrar, indica un punto crítico en la transformación de las prácticas oraculares.

\section{2. «LO POLÍTICO»Y «LO HISTÓRICO» EN LA COMEDIAARISTOFÁNICA}

\subsection{La fundación de la interpretación sociológica}

A diferencia de la tragedia, que suele remitir a un mundo épico-mitológico, la comedia aristofánica alude explícitamente a la situación de la polis y de ahí su carácter «político». Tal como lo define Gil (1996: 109): «El verdadero protagonista de las piezas [cómicas] era la polis ateniense o, mejor dicho, el conjunto de los ciudadanos que podían reconocerse en tipos simbólicos como Diceópolis, Demo o Trigeo». Sin embargo, «lo político» no fue interpretado de manera unívoca ni es algo que se sobreentienda por sí mismo, sino que forma parte de la re-construcción filológica e historiográfica que realizan los Estudios Clásicos. En efecto, desde el siglo XVIII hasta la actualidad la tradición de la Filología Clásica y de la Historia Antigua abordó con distintas perspectivas y argumentos el tema de «lo histórico» y «lo político» en la obra de Aristófanes. Sus interpretaciones pasan de negar el testimonio «histórico» y «político» de las comedias hasta afirmar que este autor era un opositor a la democracia ateniense del siglo v a.C. o que era lo contrario, un demócrata idealista. Respecto a las lecturas de la segunda posición — la más fructífera heurísticamente-, es decir, que

${ }^{3}$ Ong (1987: 84-85): «La escritura (y particularmente la escritura alfabética) constituye una tecnología que necesita herramientas y otro equipo: estilos, pinceles o plumas; superficies cuidadosamente preparadas, como el papel, pieles de animales, tablas de madera; así como tintas o pinturas, y mucho más». Havelock (1996: 116): «Sería una simplificación excesiva si situásemos las condiciones previas a la escritura y las de la civilización escrita en una simple oposición recíproca en la que ésta reemplaza a aquélla. Pero cuando menos el primer problema que hemos de resolver, si podemos, es la fecha de la invención del alfabeto, aquella tecnología superior de la palabra escrita que fue la primera en aislarlos no-sonidos consonánticos y asignarles unos símbolos visibles específicos».

${ }^{4}$ De acuerdo con el Diccionario panhispánico de dudas, puede emplearse tanto «producibilidad» como «productibilidad» en alusión a la cualidad de producible, de poder ser producido, y que no debe confundirse con «productividad» en tanto cualidad de poder producir. No obstante, la referencia aquí de «producibilidad» remite al conocido ensayo de Walter Benjamin «Das Kunstwerk im Zeitalter seiner technischen Reproduzierbarkeit» [«La obra de arte en la época de su reproducibilidad técnica»] en el cual explica la relación entre los desarrollos tecnológicos y la producción y reproducción simbólica. En un contexto premoderno, como lo era la Antigua Grecia, podría hablarse de una «producibilidad» en tanto la reproductibilidad seriada que Benjamin identifica está relacionada con la producción simbólica de masas de principios de siglo xx. Al referirnos a «producibilidad» enfatizamos la innovación radical que generó la difusión de la escritura en la cultura griega del siglo v. a.C. y, en particular, para la práctica oracular cuya tradición se remonta a tiempos de pura oralidad. 
en la obra de Aristófanes se pueden rescatar elementos históricos sobre la vida política ateniense del período clásico, la mayor parte de las indagaciones giran en torno a la posición partidaria-ideológica del comediógrafo. Este eje centrado en el aspecto biográfico-intencional del autor se remonta al siglo XIX y, como ya lo intuía Köchly $(1857,1)$, Aristófanes fue disputado, al igual que en una asamblea parlamentaria, por la izquierda y la derecha. ${ }^{5}$ Como trasfondo de las disputas por la identidad ideológica del comediográfo y de las reflexiones filosóficas sobre su comedia, estaba la instauración de Aristófanes como modelo de autor y de obra. ${ }^{6}$

En el siglo xx, dicho antagonismo mantuvo el tono deliberativo en las obras del francés Croiset (1906) y los británicos Murray (1933) y Hugill (1936) hasta la publicación del trabajo de Gomme (1938) que cuestionó la relevancia de la posición ideológica de Aristófanes para el estudio de su obra. Así, su interpretación de «lo serio» fue la clave para comprender «lo político» por fuera de la voluntad partidaria del comediógrafo. En 1972, la noción de «lo serio» fue criticada por de Ste Croix, ya que consideraba relevante conocer la posición de este autor para comprender el sentido de «lo histórico» en su obra. De esta manera, el debate respecto a la posición de Aristófanes se reinicia. ${ }^{7}$ Desde otra perspectiva, el trabajo seminal The people of Aristophanes. A sociology of Old Attic Comedy de Victor Ehrenberg (1943 [1962]) abrió una línea de investigación respecto a la utilidad de la comedia como documento «histórico». Allí, se dedicó a aplicar la sociología emergente en su época a los personajes de las comedias, instituyendo una lectura histórica-sociológica. ${ }^{8} \mathrm{Su}$ perspectiva procura interpretar la comedia como «un espejo que refleja la vida real» [a mirror reflecting real life] de la Atenas clásica (1962: 7), ${ }^{9}$ en donde «real» significa «de la gente» [real life is the life of people] (1962: 9). En este sentido, la comedia Antigua tiene validez como

${ }^{5}$ Köchly $(1857,1)$ : «Wie bei einer parlamentarischen Versammlung, so treten auch hier zunächst in schärfstem Gegensatz eine Rechte und eine Linke sich gegenüber».

${ }^{6}$ En Alemania, estas disputas fueron encabezadas, principalmente, por Ernst Curtius, Johann Droysen, Hermann Müller-Strübing y Theodor Kock, aunque ya existían ecos de esta disputa en el siglo XVIII. Por ejemplo, a fines del siglo XVIII, Johann Georg Schlosser presentaba a Aristófanes como modelo del arte crítico, arte que serviría de sublimación para la clase dominada y de iluminación para la clase dirigente. Este traductor de Ranas (1783) — traducción encargada por Goethe- definió la obra del comediógrafo como de «un patriotismo noble, masculino, audaz» (137). Esta postura confrontó con la de otro traductor coetáneo: Christoph Wieland (Acarnienses, 1794; Caballeros y Nubes, 1798; Aves 1806). Este filólogo negaba la influencia política de la comedia y la reducía al divertimento del público, lectura de un Aristófanes proaristocrático que se justificaba en el rechazo a los ideales de la Revolución francesa. A diferencia de Wieland, Schlegel (1794) y Kanngieser (1817) sostenían la idea de que la comedia Antigua representaba la verdadera poesía democrática en oposición a la tragedia aristocrática. La comedia sería, así, una institución que funcionaba como «tribunal crítico» (Kanngieser; 1817, 193). En el contexto de los ideales de la Revolución Francesa, la obra de Aristófanes fue utilizada también para la especulación filosófica de la estética. Los hermanos Schlegel, Heine y Hegel reconocieron en el carácter crítico-político de la comedia la manifestación suprema de la libertad y la democracia. Ver Holtermann (2004); Walsh (2009); Rebenich (2012); Kitzbichler (2014).

${ }^{7}$ Los trabajos más significativos en esta línea pertenecen a Kraus (1986), Heath (1987, 1997), Henderson (1990), Sommerstein (1998), Sidwell (2009).

${ }^{8}$ Siguiendo esta línea, se encuentran investigaciones sobre economía (Spiegelvögel: 2001), sobre género (Foley: 1981; Henderson: 1987, Taaffe: 1993) y sobre derecho (Buis: 2009, 2011, 2013).

${ }^{9}$ Las citas pertenecen a la edición de 1962. 
fuente para la historia económica y social, ya que ilustra de manera «inconsciente» la vida «real» y provee no solo hechos [facts]. Por supuesto, aclara Ehrenberg, esta empresa necesita de otras evidencias para completarse. Ellas contribuyen a recrear la «atmósfera» producida por las condiciones sociales y económicas de vida, atmósfera que solo es recuperable en la comedia (1962: 11-12). La comedia se convierte así en un tipo único de evidencia, ya que brinda un testimonio que ninguna otra fuente ofrece (1962: 12).

Metodológicamente, Ehrenberg señala que las posibles fuentes que disponemos para el estudio de la Antigüedad son la evidencia arqueológica, numerosas inscripciones y monedas, varios discursos retóricos, tratados filosóficos y una cantidad considerable de textos literarios, entre ellos la comedia. Ehrenberg afirma que sacar conclusiones históricas sobre la base de evidencia arqueológica es riesgoso, a menos que puedan ser chequeadas con otras fuentes. Por el contrario, las monedas e inscripciones son fuentes más fiables y son «matter-of-fact», aunque no está seguro de que respondan a hechos reales [real facts], ya que deben comprenderse en unidad, en contexto. Tanto la comedia como cualquier fuente literaria necesitan un tratamiento distinto, ya que la mirada parcial del relato impide una interpretación directa de lo narrado. Del «trasfondo» [the background picture] siempre se podrá extraer algo verdadero de los hechos, un trasfondo que es evidente para el poeta y la audiencia, aunque hasta cierto punto sea imposible separar el propósito del autor de su punto de vista (1962: 6). Como argumento complementario, Ehrenberg incluye el factor psicológico - también en consonancia con la emergencia de la psicología como disciplina- que reflejan las obras literarias, puesto que la vida social no se compone solo de hechos, sino también de reacciones psicológicas de los individuos. Es decir, es necesario saber también de qué manera en ciertas circunstancias económicas piensan y actúan los hombres. Aclara, por último, que estas reacciones no son reconstrucciones abstractas, sino que también son hechos que conforman la «atmósfera» de una época (1962: 6-7). ${ }^{10}$ «Lo político» y «lo histórico» aparecen así bajo una perspectiva materialista y justifican el uso de la comedia como testimonio que permite reconstruir la «atmósfera» que generaban las condiciones económicas y sociales de la Atenas clásica.

\subsection{La dimensión performática: metateatro como crítica social}

Como fruto de una tradición centrada en los estudios teatrales, el trabajo de Slater (2002) trae una nueva forma de abordar «lo político» y «lo histórico» en la obra aristofánica. En un punto intermedio entre el análisis denominado close reading y las formulaciones respecto a la función institucionalizada del teatro, este investigador pone en primer plano la dimensión performática de la comedia aristofánica y, en particu-

${ }^{10}$ Una definición similar propone Schwarze $(1971,1985)$ en su estudio sobre la imagen de Pericles en la comedia ática: «Die historiograpische Bedeutung, die man demgegenüber dem Komödienspott nun wirklich zugestehen kann, liegt nicht in dem komischen Bild des Perikles und darin, daß man dieses Bild etwa gegen das grundlegende Urteil des Thukydides ausspielen könnte. Dazu trägt es viel zu deutlich den Stempel "komischer" Originalität. Der Beitrag der Komodie liegt vielmehr in den aktuellen Spiegelungen des "perikleischen Zeitalters", also in dem, was sich an politischer und aktueller Substanz von den Bühneneffekten isolieren läßt.» Cursivas mías. 
lar, de lo metateatral. ${ }^{11}$ Los estudios sobre metateatralidad aplicados al drama antiguo brindaron una serie de elementos útiles para comprender la dimensión espectacular y escénica de tragedias y comedias cuyo único testimonio contemporáneo es textual. ${ }^{12}$ En un inicio, estos estudios se focalizaron en las comedias de Aristófanes por el carácter paródico literal de, por ejemplo, Las tesmoforias y Ranas. A partir de este antecedente, la tragedia también fue abordada desde esta perspectiva, siendo los autores más «ricos» en elementos metateatrales Sófocles y Eurípides.

No obstante, la novedad del abordaje de Slater reside en su concepción metateatralextrateatral de la comedia; es decir, su interpretación de la representación aristofánica como crítica a los modos de representación ritual de las prácticas sociales. Esta crítica no se limita solo a la lectura paratrágica, ${ }^{13}$ sino que se orienta a la interpretación satírica de las prácticas sociales, como pueden ser las tribunalicias, asamblearias, mánticas o comerciales. Según Slater, este tipo de crítica le enseñaría a la audiencia sobre el grado de persuasión de dichas prácticas en tanto «construcciones» sociales. Tal afirmación se puede reconocer, por ejemplo, en la desarticulación de las estrategias de los agones aristofánicos (2002: 236). Lejos de diferenciar la lectura «estética» y la «política», este autor comprende la complementaridad del análisis de la dimensión performática. Allí donde Aristófanes parodia explícitamente a Eurípides, lo haría por el tipo de sofística que promueve en sus tragedias, en el sentido de corromper a la audiencia. Precisamente, su crítica paródica metateatral estaría orientada a señalar el riesgo que implican la retórica sofística y sus técnicas de persuasión para la democracia ateniense (2002: 237). En este sentido, la metateatralidad aristofánica no solo es una mera referencia paratrágica, sino también una advertencia sobre la manupiluación teatral de la vida política de Atenas (2002: 239). Slater define así que «lo metateatral es en su naturaleza metacrítico: al abrir el proceso teatral a nuestra mirada, nos invita

${ }^{11}$ Este concepto de «metateatro» tiene su origen en la publicación de Metateather: A new view of dramatic form Lionel Abel (1963), quien lo definió como «la-obra-dentro-de-la-obra» y de «dramaturgodentro-de-la-obra». En el transcurso de distintos estudios, el campo de lo metateatral no solo se extendió hasta el teatro antiguo, sino que también fue expandiendo la idea llana de «obra-dentro-de-la-obra», ocupándose de toda forma de auto-referencialidad teatral. Esto incluye formas de alusión conciente a convenciones dramáticas, juegos/intercambio de roles, representación de rituales, rupturas de ilusión dramática, etc. Es decir, el fenómeno metateatral pone el foco en el sistema semiótico de la práctica dramática, subrayando la dualidad de la experiencia escénica. Se desdobla así, por un lado, la ilusión del drama y, por el otro, la apreciación de la audiencia sobre los mecanismos y convenciones de la ilusión, generando la reflexión sobre el qué se representa dentro de la obra pero también sobre el cómo se representa.

12 Bain (1977), Taplin (1977, 1978), Gentilli (1979), Goldberg (1980), Hubbard (1991), Bier (1991), Taaffe (1994), Ringer (1998), Barrett (1998), Foley (2008), Ruffell (2008).

${ }^{13}$ Hasta la publicación de Rau (1967) Paratragodia. Untersuchungen einer komischen Form des Aristophanes, la investigación sobre la parodia aristofánica se había ocupado de la definición de un concepto de parodia, del reconocimiento de las parodias y de la reconstrucción de pasajes perdidos de otras obras (1967: 1). Rau señala la carencia de una distinción nítida entre la parodia como crítica, la paratragedia como imitación acrítica y la tragicomedia como combinación de estructuras trágicas con elementos cómicos. En este punto, Rau realiza su contribución al analizar el aspecto «positivo» de la parodia trágica como forma particular de la comedia. Básicamente, se pregunta qué es lo realmente cómico en la parodia. Para ello, deberían indagarse los elementos formales y motivos que emplea Aristófanes como forma de lo cómico y, de esta manera, al reconocer sus propios medios formales, se podría evaluar los criterios estéticos de la «calidad poética» [poetische Qualität] de su parodia (1967: 4). 
a contemplar no solo la cualidad [quality] sino los objetivos [goals] de la producción [performance] teatral» (2002: 7). ${ }^{14}$ Este abordaje disolvería, de esta manera, la dicotomía de «lo serio» y «lo gracioso», sobre la que se basaron las lecturas «estéticas» frente a las «políticas» y evita la reducción de lo metatetral a lo paratrágico.

La contribución de Slater se da tanto en la discusión sobre «lo histórico» y «lo político» en Aristófanes como en el registro de lectura que propone. Además de la labor filológica, habilita la interpretación escénica-performática, con todo lo que ello permite explorar: desde las retóricas y acciones de los personajes hasta las materialidades que implican dichas prácticas sociales (la escritura, la vestimenta). De esta manera, su aporte abre nuevas vías de investigación sobre el teatro mismo y sobre las prácticas sociales que conformaban la vida política de la Atenas clásica, pero también cómo ambas se influían mutuamente.

\section{EL ORÁCULO DE DELFOS DURANTE LA GUERRA DEL PELOPONESO}

\subsection{Las esperanzas claras por las oscuras: la adivinación según Tucídides}

A lo largo de su obra La Guerra del Peloponeso, Tucídides menciona los oráculos en reiteradas ocasiones. Se refiere escépticamente a la adivinación, abriendo un manto de sospechas sobre su autoridad. ${ }^{15}$ En boca de los atenienses, Tucídides explica el vínculo entre la esperanza en una circunstancia crítica y los mecanismos para apaciguar dicha incertidumbre. Opone así las esperanzas «claras» ( $\varphi \propto v \varepsilon \rho \alpha i)$ a las «oscuras»

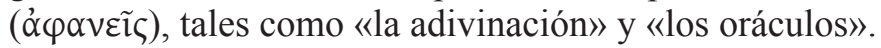

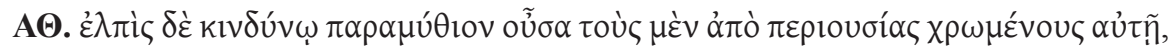

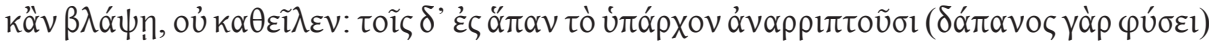

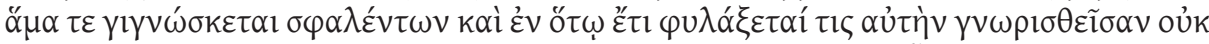

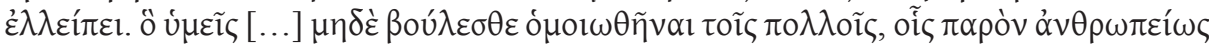

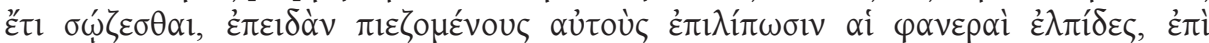

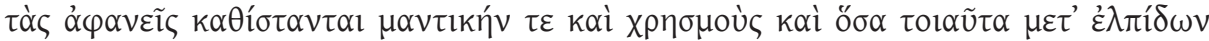

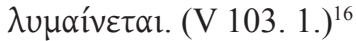

Atenienses: «La esperanza, un estímulo en el peligro, aunque llegara a dañar a los que acuden a ella desde un estado de prosperidad, no les arruina; pero a quienes apuestan todo por ella les conduce a la derrota (pródiga por naturaleza) y ya no les da posibilidad de resguardarse una vez que se la ha conocido. Vosotros [...] no queráis asemejaros a los muchos que en una situación crítica, pudiendo salvarse por medio de su con-

${ }^{14}$ Cursivas del autor.

${ }^{15}$ El análisis de los pasajes se centra en la descripción de la crisis de la autoridad mántica y no resulta relevante para este trabajo señalar la posición de Tucídides respecto a lo supersticioso o lo irracional, sobre lo que varios autores han problematizado. Ver Marinatos (1981), Jordan (1986), Hornblower (1992), Powell (1979), Mikalson (1984), O’Hara (1991), Muñoz Llamosas (2001), Oost (1975).

${ }^{16}$ Seguimos la edición de Jones, H. S., ed. (1900) Thucydides Historiae. Oxford. Revisado por J. E. Powell. 1942. 
dición humana, les abandonan las esperanzas claras y caen en las oscuras, tales como la adivinación, los oráculos y todas aquellas [prácticas] que con las esperanzas causan ruina».

Según Tucídides, los oráculos producen esperanzas oscuras. Pero ¿qué comprende por oscuro? Por un lado, Tucídides sugiere una novedosa sobreproducción y sobrecirculación de oráculos con motivo de la guerra y no solo en Atenas, sino en todas las polis: «Circulaban muchas profecías, y muchos cresmólogos [las] andaban recitando,

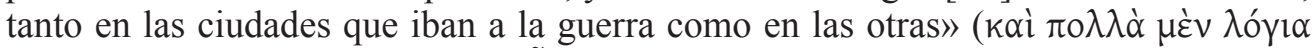

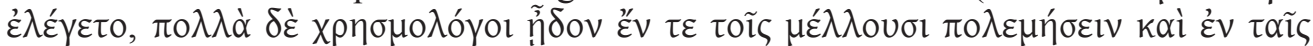

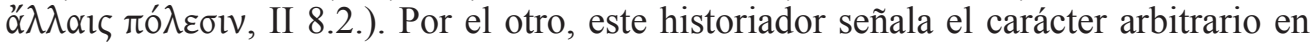
la interpretación de los oráculos: «Había cresmólogos que pronunciaban todo tipo de

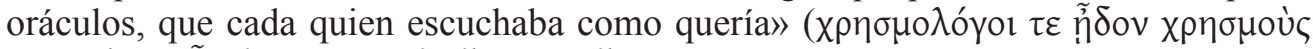

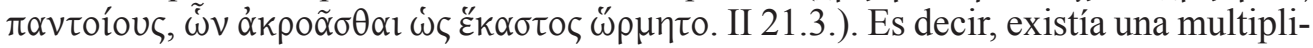
cidad de sentidos que no estaban regulados y controlados por una autoridad.

Esta no es, sin embargo, la única causa por la que los oráculos y la adivinación eran prácticas «oscuras». El acceso al templo de Delfos era en sí una disputa de poder. Para poder obtener la información «divina» había primero que llegar a Delfos y esto debía ocurrir bajo las normas de la costumbre. Tal como señala Tucídides en el acuerdo de paz, Atenas debía tener acceso a Delfos «sin engaño y sin recelo de acuerdo con las

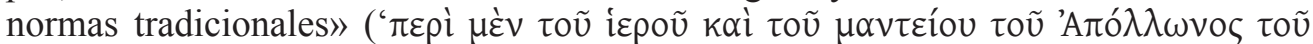

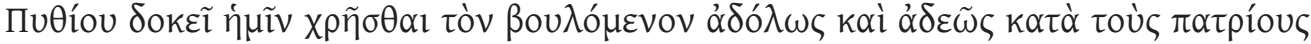
vóuous. IV 118.1.). Que los oráculos y los adivinos llegaran a la polis en un contexto de creciente incertidumbre generaba una sobreproducción de «informaciones divinas». El proceso inverso, o sea, ir directamente a la «verdadera» fuente del saber oracular, el mismo templo de Delfos, estaba también restringido por la situación bélica, lo que volvía más inestable el procedimiento «normal» de la consulta al oráculo. Incluso, Tucídides cuenta cómo Plistoanacte había persuadido a un adivino de Delfos

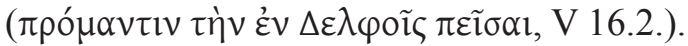

De acuerdo con estos pasajes de Historia de la Guerra del Peloponeso, el proceso de consulta al oráculo délfico estaba por fuera de «la costumbre». Sin embargo, esta irregularidad no obstaculizaba la necesidad de apaciguar la incertidumbre provocada por la guerra, sino que producía el efecto contrario: había una sobreproducción de oráculos que iba de la mano de una sobrecirculación. A su vez, esta sobreproducción y su sobrecirculación permitían las condiciones para la multiplicación de intérpretes e interpretaciones, lo que generaba una inflación de autoridad mántica y de legitimidad en el establecimiento de «un» sentido. Tucídides describe así este fenómeno pero no explica los elementos socio-técnicos que posibilitan dicha crisis en la legitimidad mántica. La escena del cresmólogo intruso en Aves permitiría brindar una descripción de dicho fenómeno a través de la comprensión de su funcionamiento como práctica socio-técnica.

\subsection{Vete a «cresmologuear» con los biblioi a otra parte}

El carácter crítico-utópico de Aves ejerce una mirada etnográfica particular sobre la propia Atenas, siendo su argumento la fundación de Cucópolis de las Nubes, una colonia 
que se instituye como una anti-Atenas y cuyas características remiten a una Edad de Oro. Esta «fantasía política» (Arrowsmith: 1973) representa cómicamente la tensión entre phýsis-nómos y apragomosýne-polypragmosýne. En los primeros 850 versos se describe cómo funcionaría Cucópolis. Tras este manifiesto utópico, aparece un sacerdote con la intención de iniciar los ritos sagrados de la fundación. Este es el inicio de lo que la crítica filológica denominada la «escena de intrusos». Luego, aparecen el poeta, el cresmólogo, el astrónomo Metón, el inspector y el vendedor de decretos. Estos intrusos representan la institucionalidad y el saber burocrático que esta nueva polis no quiere implementar. A diferencia de otras comedias como Acarnienses y Caballeros en las que la crítica apunta directamente contra la figura del poder, o sea, Cleón, en Aves Aristófanes se burla de los mediadores que ejercen el poder en la vida cotidiana. De esta manera, el comediógrafo pone el foco en cómo la normativa de Atenas referida a la ley, la ciencia y las prácticas rituales afecta a los ciudadanos. Aves sería así una crítica a la mediación del poder político y de los dioses, mediación que se cristaliza en las convenciones entendidas como normas.

$\mathrm{Al}$ igual que el sacerdote, el poeta y el astrónomo quienes querían imponer su nómos a cambio de un rédito, el cresmólogo es echado a golpes por ser charlatán

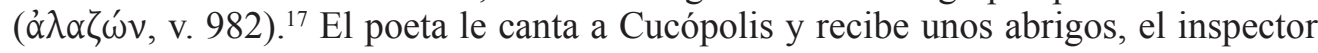
viene a cobrar el impuesto de la nueva colonia y el vendedor de decretos trae nuevas leyes que deben ser compradas. Por su parte, el cresmólogo se presenta para leer los oráculos que legitimen la fundación de la ciudad de las aves. ${ }^{18}$ Sin embargo, este personaje no dice directamente que debe recibir un beneficio por su ejercicio, sino que lo hace en forma enigmática a través de un oráculo que es leído con interrupciones. A continuación, se cita el oráculo completo:

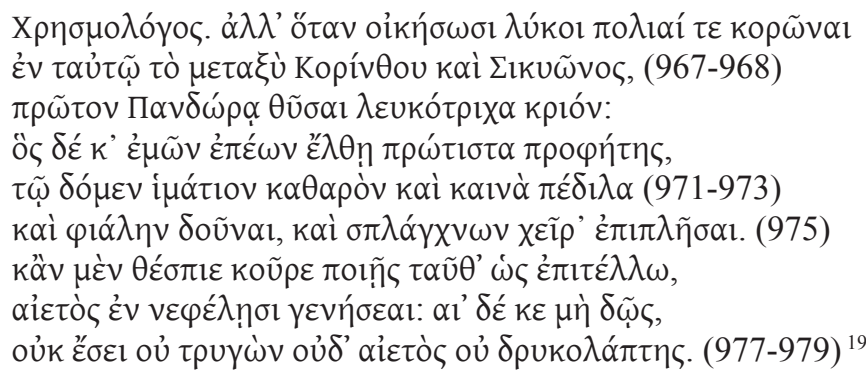

Cresmólogo: «Pero cuando vivan el lobo y la pardela gris juntos en el medio de Corinto y Sición...»

[...] «Primero sacrificar un carnero blanco para Pandora, $\mathrm{y}$, cuando llegue el primer profeta de mis palabras, darle un traje limpio y un par de botas nuevas.» [...] «y darle una copa y llenarle las manos de entrañas [de sacrificios].»

\footnotetext{
${ }^{17}$ Aristófanes también califica a Hierocles en La paz con este término (v. 1069).

${ }^{18}$ Sobre los impuestos en los cultos griegos, ver Sokolowski (1954).

${ }^{19}$ Aquí se muestran los versos que representan el oráculo del cresmólogo, cuyo recitado es interrumpido por Pistetero. De allí, viene su fragmentación. Seguimos la edición comentada de Dunbar (1997).
} 
$[\ldots] \ll Y$, si realizas tales cosas que prescribo, joven inspirado por los dioses, te convertirás en águila de las nubes, pero si no lo haces, no serás ni tórtola, ni águila, ni [pájaro] carpintero...» ${ }^{20}$

Este oráculo reproduce la forma de aquellos que circulaban por la Atenas del siglo v a.C. Se lo reconoce por los hexámetros dactílicos - la métrica habitual de los oráculos griegos - y las imágenes de animales, como el águila y su remisión a Atenas, pero también por su inicio $\alpha \lambda \lambda \lambda^{\prime}$ ó $\alpha \alpha \nu$, característico del género oracular. ${ }^{21}$ En cuanto a su sentido, el comediógrafo retoma un tópico recurrente en «la memoria cultural»» ${ }^{22}$ de la Antigua Grecia en torno a los adivinos y la corrupción del saber mántico. Así como en Herodoto existen varios episodios en los que los oráculos u otras formas de adivinación son manipulados tanto en su registro como en su interpretación, ${ }^{23}$ la denuncia de corrupción mántica también aparece en algunas tragedias (Soph. Ant. vv. 1033-1061; Soph. OT vv. 380-403; Eur. Bacchae vv. 255-257). Mientras en Caballeros se acusa a Paflagonio de «oraculizar» la polis en su favor (v. 819) ${ }^{24}$ y en $\mathrm{La}$ Paz el adivino Hierocles impide que cese la guerra, Aristófanes ridiculiza en Aves la figura del cresmólogo al hacerle recitar un oráculo demasiado evidente que termina funcionando como una denuncia de carácter auto-profético ${ }^{25}$ sobre la manipulación del saber mántico.

Pistetero, el personaje que no se amedrenta con ningún representante del nómos ateniense, realiza un gesto bastante recurrente en la obra aristofánica: emplea la misma estrategia del «poderoso» pero en su contra. Develando el oráculo autoprofético del cresmólogo, este personaje crea su propio enigma. La inversión de roles e imágenes pone aún más en evidencia el uso manipulable al que son susceptibles los oráculos. Esto se observa principalmente tanto en la apropiación de la lógica del oráculo («si ocurre tal cosa, entonces...») como en el empleo de términos ya pronunciados por el cresmó-

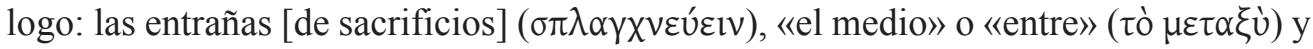

${ }^{20}$ Las traducciones me pertenecen.

${ }^{21}$ Suárez de la Torre (1998: 199) plantea una hipótesis interesante respecto al estilo oracular en la que existe una contaminación entre los oráculos «serios» de documentos históricos y aquellos de la tragedia y la comedia. De esta manera, al igual que propone Slater, los límites entre práctica social y representación dramática se vuelven difusos. Por otro lado, de acuerdo con Dunbar (1998: 368), la frase

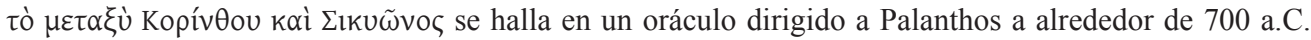
(Diodoro Sículo 8.21.3).

${ }^{22}$ Assmann (2000: 52): «Para la memoria cultural no cuenta lo fáctico, sino sólo la historia recordada. Se puede decir que en la memoria cultural la historia fáctica se transforma en historia recordada y, por ende, en mito». Como bien analiza Suárez de la Torre (1998), la tradición del motivo mántico en clave paródico-satírica se puede rastrear en Arquíloco e Hiponacte.

${ }^{23}$ Tal como lo desarrollan Barker (2006) y Hollmann (2005), existen varios episodios en Herodoto en los que no solo se manipula el oráculo para realizar un engaño, sino también otros sistemas de signos (militares, vestimenta, inscripciones, presagios).

${ }^{24}$ Para un análisis en detalle de la adivinación en Caballeros ver Suárez de la Torre (1998), Bartoletti (2015). Sobre la adivinación en Aristófanes, Smith (1989).

${ }^{25}$ Por carácter auto-profético, se entiende la profecía que alude al momento de su profecía o a una profecía que habla de sí misma. Sugerimos como clave de lectura «lo auto-profético» en lugar de «lo meta-profético» en la medida que no hay una reflexión en términos proféticos sobre la profecía, sino una referencia a sí misma como «esa» profecía puntual de la escena. 


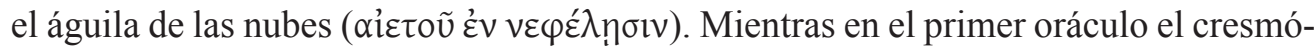

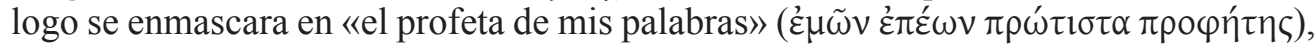
el oráculo de Pistetero lo trata de «charlatán» ( $\alpha \lambda \alpha \zeta \omega ́ v$, v. 982). Concluye, por otro lado, haciendo referencia a dos personajes públicos vinculados a los oráculos griegos y la religión ateniense: Lampón y Diopites. El primero fue un adivino histórico que participó en la fundación de colonias y en la campaña de Sicilia (Tucídides VIII 1.1., Plutarco Nic. 13). El segundo es famoso por su decreto (432 a.C.) que perseguía a quienes no creyeran en las cosas divinas o enseñaran los fenómenos celestes (Plutarco Vida de Pericles, XXXII). Este decreto marcó el inicio de los juicios por asebia, entre otros, contra Anaxágoras, quien era vinculado a Pericles, y posteriormente contra Sócrates. La alusión a estos dos personajes públicos de autoridad religiosa incrementa la crítica a la manipulación de los oráculos, pero ya no atacando al cresmólogo intruso en particular, sino a la institución adivinación en general.

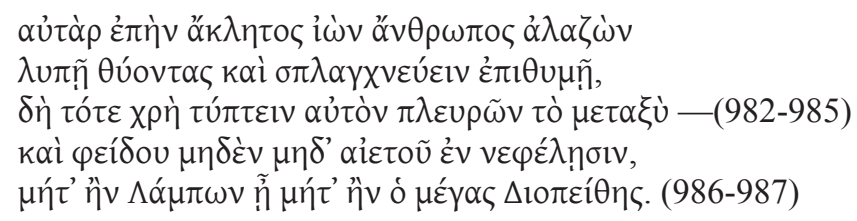

Pistetero: Pero cuando venga de imprevisto un charlatán

Moleste a quienes ofician los rituales y quiera las entrañas [de sacrificio]

Entonces hay que golpearlo en el medio de las costillas

No respetes a nadie: ni al águila de las nubes

$\mathrm{Ni}$ a Lampón que fuera o al gran Diopites.

Lo que ambos oráculos muestran es la capacidad poética de Aristófanes para parodiar el género oracular. Si se conocen las características de los oráculos y se tiene su arte, su techné-poietiké, entonces pueden ser creados. Sin embargo, la autenticidad $\mathrm{y}$, en consecuencia, la autoridad de cada oráculo también se fundamenta en su origen o su «certificación», legitimidad otorgada por la tradición o el nómos. Mientras el

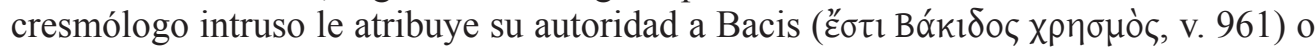
interpreta lo que éste quiso decir en enigmas, la hermenéutica propia de los adivinos

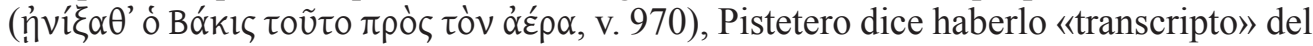

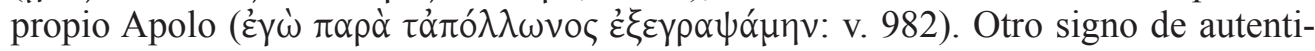
cidad a partir del cual el cresmólogo intruso quiere lograr autoridad es la mostración del papel donde está transcripto el oráculo. Ante la sospecha de Pistetero sobre su veracidad, el cresmólogo intruso responde en reiteradas ocasiones: «Toma el papel»

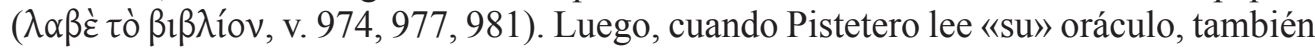
le dirá $\lambda \alpha \beta \dot{\varepsilon}$ tò $\beta ı \beta \lambda i ́ o v ~(v . ~ 986,989)$. Este elemento indica el valor de autenticidad que comenzó a serle atribuido al soporte material y a la escritura en un contexto de desarrollo y difusión de dicha tecnología. De esta manera, Aristófanes ya no solo estaría parodiando el género oracular, sino también satirizando la práctica de legitimación y validación de significados que era ejercida en la Atenas del siglo v a.C.. El conjunto de estos elementos (los enigmas, las inscripciones, la autenticidad) aparece sintetizado 
en boca de Pistetero cuando verbaliza la denuncia contra el cresmólogo diciéndole que

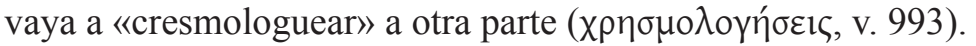

Mientras Aristófanes recrea poéticamente el estilo y las imágenes de los oráculos griegos, también reproduce y devela cómicamente las condiciones y prácticas que daban sustento y legitimidad a los oráculos. La complejidad de la crítica hecha por Aristófanes a la manipulación de los oráculos se basa, primero, en evidenciar el juego retórico-poiético del discurso enigmático de los oráculos y, en segundo lugar, en poner la lupa sobre su práctica material, oral y escrita. La puesta en evidencia de dicho funcionamiento se da tanto por el propio carácter de la comedia y su caricaturización de comportamientos y elementos, pero, en particular, por la fantasía política de Aves que genera una otredad sobre la propia cultura. Usando dicha «lupa cómica», el análisis «micro» de la escena del cresmólogo intruso en Aves nos permite señalar dos elementos centrales en la producción de informaciones divinas: por un lado, el soporte escrito y su re-producción oral y, por otro lado, la poiesis enigmática y su competencia hermenéutica.

\section{ORALIDAD Y ESCRITURA DE LOS ORÁCULOS GRIEGOS}

La escena del cresmólogo intruso en Aves refleja cómicamente la práctica de lectura e interpretación de oráculos en público. ${ }^{26}$ De los elementos satirizados, se destacan a través de la burla la materialidad de la escritura (los biblioi), el origen o «certificación» del oráculo (Bacis o Apolo) y la legitimidad general de la institución adivinación (Lampón, Diopites). Sin embargo, para evidenciar la relación entre la autoridad mántica y la escritura como tecnología durante la Guerra del Peloponeso, es necesario analizar otros testimonios de dicho fenómeno. Estos permitirán mostrar el «uso» y «desuso» de la práctica mántica para comprender el «abuso» que denuncia cómicamente Aristófanes.

\subsection{Monopolio del saber mántico}

Los primeros santuarios oraculares, como los de Delfos u Olimpia, se establecieron durante el siglo vIII a.C. en sitios marginales, ocupando un rol central en la comunicación entre distintas poleis dado su locación «neutral». A través de estos santuarios se institucionalizaban cultos, que eran constitutivos en la construcción de su identidad. Entre las varias prácticas rituales que se daban en estos santuarios, estaban también las consultas oraculares que funcionaban como mecanismos que les permitían a las autoridades de las comunidades emplear sanciones divinas para lograr consenso en la toma de decisiones políticas. Es decir, las consultas se hacían sobre temas excepcio-

\footnotetext{
${ }^{26}$ Slater (1996) oportunamente observó que los estudios fundadores sobre oralidad y escritura en la democracia ateniense del siglo v a.C. (Harris: 1989; Thomas: 1989 \& 1992) omitieron la comedia como corpus. Dos trabajos posteriores como el de Baumgarten (1998) y Henrichs (2003) integran los testimonios de la comedia aristofánica con el eje entre lo sagrado y lo escrito, ocupándose de la diferencia entre «texto sagrado» y «libro sagrado».
} 
nales que excedían la sabiduría colectiva de la elite y que, por lo general, se daban en situaciones sin precedentes o que podrían producir divisiones entre grupos sociales con distintos intereses. ${ }^{27}$ Como está documentado en diferentes fuentes e inscripciones, los oráculos eran una práctica basada en el lenguaje. Eran una producción poiética de aenigmata y los aenigmata eran un género particular con una tradición sapiencial propia. ${ }^{28}$ Originalmente, los oráculos eran un corpus textual de tradición oral viva, que incluía diversas respuestas oraculares que se componían y re-componían de acuerdo a situaciones particulares. Como explica Maurizio (1997) respecto al episodio del muro de madera en Herodoto (VII 140-144), un oráculo formaba parte de la tradición délfica - en este caso - una vez que la asamblea lo avala por medio de la práctica oracular. Su credibilidad le era otorgada por medio de una competencia de interpretaciones que era lo que finalmente le daría autenticidad. Esto quiere decir que se la consideraba «divina» con valor predicativo y que esta aceptación permitía que se la recuerde e introduzca en la tradición.

Antes de que se insertara la escritura al mundo griego, la producción, reproducción y circulación de oráculos era oral. Con la emergencia del uso de la palabra escrita, la forma de circulación de los oráculos no fue reemplazada, aunque sí modificada. La convivencia entre una cultura tradicionalmente oral ante la inserción de un nuevo sistema técnico como la escritura plantea trading zones. ${ }^{29}$ A partir del siglo vi a.C., la conservación escrita de oráculos fue uno de los primeros usos de la escritura en la Antigua Grecia. De esta manera, se registraba la comunicación entre hombres y dioses. Además, la escritura se volvió un medio de circulación que no lo hacía depender de la consulta particular, sino de la colección para interpretar situaciones cruciales, algo similar a lo que ocurría con los Libros Sibilinos en Roma (Rosenberger: 2001b, 82-87). Por ello, las ciudades acopiaban y archivaban oráculos. Uno de los primeros episodios sobre los oráculos y su paso a la escritura puede encontrarse en Herodoto. En el libro VII (6. 3), se relata la historia de Onomácrito a quien Pisistrato había encomendado realizar una colección con los oráculos de Museo. Según Rosenberger (2001a: 168) este encargo sería un intento por «monopolizar el saber profético». Pero, de acuerdo con el episodio narrado por Herodoto, Onomácrito también es conocido por haber querido interpolar versos en un oráculo, lo que le costó el destierro. De este episodio se puede concluir que existía en la Grecia Antigua una relación entre poder y saber que era mediado técnicamente a través de la escritura. De esta manera, la escritura de los oráculos permitía, por un lado, la concentración de su saber y, por el otro, la restricción a su acceso o, por lo menos, otra forma de circulación, aunque también esta mediación guardaba la posibilidad de su fraude. Cabe señalar que el valor de las colecciones de oráculo no se limitaba a la esfera pública. En su Eginético (19.5), Isócrates cuenta el caso del adivino Polemaineto, que dejó su biblioteca de libros sobre

${ }^{27}$ Morgan (1990: 1-25), Kindt (2001), Rosenberger (2001a), Eidinow (2013).

${ }^{28}$ Kwapisz, Petrain, Szymański (2013), Monda (2012), Luz (2010) Berra (2008), Iriarte (1990: 49-64).

${ }^{29}$ Galison (1997) introdujo el término «trading zone» al campo de la sociología del conocimiento para superar el problema kuhniano de la «inconmensurabilidad» entre paradigmas. La consecuencia de ello es, primero, la negación de paradigma científico como algo monolítico y, segundo, explicar cómo se da la comunicación-intercambio entre dos grupos, culturas o tradiciones donde existe algún tipo de «inconmensurabilidad», Gorman (2002), Collins \& Evans (2002). 


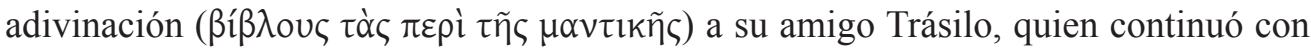
la profesión de mántis.

Otro testimonio similar sobre la monopolización del saber oracular puede encontrarse también en Caballeros. En esta comedia, el Morcillero acusa a Paflagonio de go-

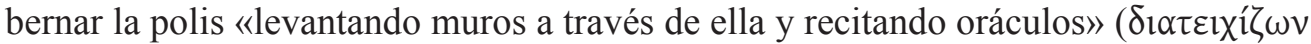

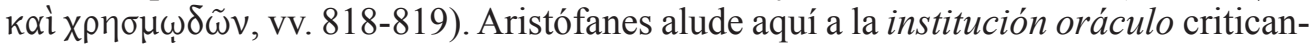
do a Cleón y a su modo demagógico de construir poder. Tanto en Aves como en Caballeros el acto de «cresmologuear» y recitar oráculos aparece bajo sospecha de manipulación. No obstante, en Caballeros Aristófanes refuerza el énfasis del soporte material escrito como elemento de autoridad mántica. La burla sobre los escritos oraculares no ocurre sobre el acto de mostración como en Aves, sino sobre la cantidad de oráculos «acumulados»y «monopolizados». Si Cleón dice tener un cofre lleno de oráculos

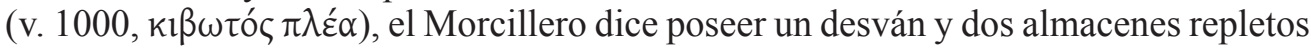

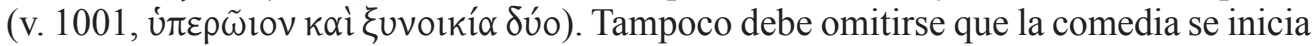
cuando Demóstenes y Nicias consiguen un oráculo escrito que Cleón había escondido (v. 110). Es decir, ya no se trata solamente de la autoridad que representa la escritura o quién pronunció el oráculo, sino quién los colecciona, almacena y controla su acceso y difusión. Tal como señala Suárez de la Torre (1998: 177) la profusión de las colecciones de oráculos se debía más a un uso político que a una necesidad religiosa. La burla aristofánica a esta profusión pone en evidencia, precisamente, la potencialidad de monopolizar el saber oracular, fenómeno que sería posible a partir de la aparición de la escritura como tecnología de difusión y almacenamiento de información.

\subsection{El oráculo en la oratoria ateniense}

A diferencia de los testimonios de Herodoto o Aristófanes, en especial los agones oraculares de Caballeros, Aves y $\mathrm{La}$ Paz, la oratoria ateniense del siglo vi a.C. nos muestra otro uso del saber oracular escrito. En efecto, si la comedia aristofánica pone en evidencia la influencia de los oráculos en las decisiones públicas, Demóstenes en Sobre la embajada fraudulenta (19. 297-298) remite a un oráculo no para legitimar una decisión sino para convencer a través de su interpretación persuasiva.

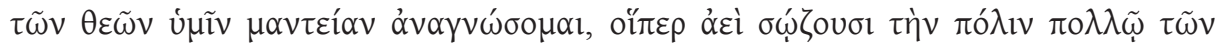

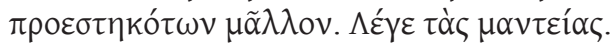

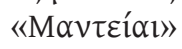

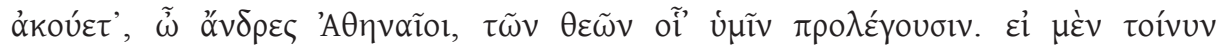

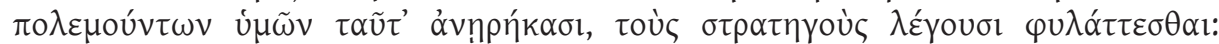

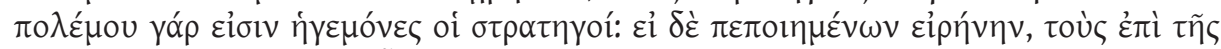

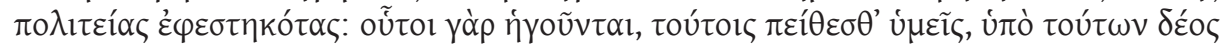

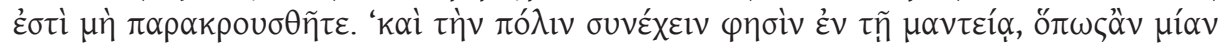

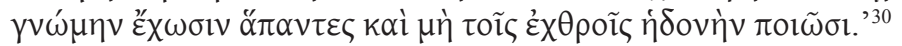

${ }^{30}$ Seguimos la edición de MacDowell, D. (ed.) (2000) Demosthenes: On the False Embassy (Oration 19). Oxford. 
Os daré a conocer un oráculo de los dioses, quienes siempre protegen la ciudad mucho más que los que están al frente de ella. Lee los oráculos

\section{ORÁCULOS}

Hombres de Atenas, oís lo que les advierten los dioses. Si os han respondido con esos oráculos en tiempos en guerra, dicen que os guardéis de los generales. Pues son los generales los que conducen la guerra. Pero si lo dicen cuando habéis logrado la paz, estad atentos a quienes están al frente del gobierno: ellos os guían, en ellos confiáis vosotros, por ellos asumís el riesgo de ser traicionados. «Y mantener unida la ciudad - dice en el oráculo - para que todos tengan un único designio y no propor cionen satisfacción a los enemigos.»

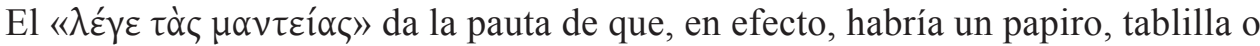
biblos a partir del cual se leía en público este oráculo. No es posible deducir del uso que aquí hace Demóstenes si se trata de una colección de oráculos o de un biblos singular, pero se puede inferir que sería un oráculo pronuciado y archivado fuera de una situación de consulta particular. Se trata, más bien, de un oráculo ex situ, en tanto Demóstenes ofrece una interpretación situacional de acuerdo con el contexto: durante tiempos de guerra y durante tiempos de paz. Un oráculo sin anclaje a una situación determinada deja de tener su función resolutiva para ser un «catálogo»o «archivo» de la sabiduría colectiva tradicional. Por otro lado, este uso de la palabra escrita en la oratoria no es exclusivo de los oráculos. En reiteradas ocasiones, De-

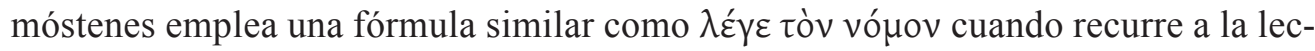
tura de leyes, lo mismo con los decretos ( $\psi \eta \dot{\varphi} \varphi 1 \sigma \mu \alpha$ ), testimonios ( $\mu \alpha \rho \tau v \rho i ́ \alpha)$ o maldiciones (ápó), por ejemplo, en Contra Macártato $(62,70,75)$ o Contra Leptines (27,

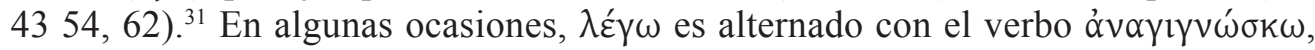
en su sentido de «re-conocer» algo escrito. En particular, en Contra Macártato (67), Demóstenes realiza una equivalencia al comparar una ley de Solón con un oráculo

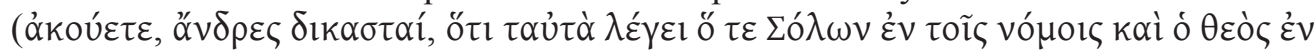
$\tau \tilde{n} \mu \alpha \nu \tau \varepsilon i ́(\alpha) .{ }^{32}$ La equivalencia no solo está dada por el sentido de la ley y el oráculo, sino también en la perfomance de lectura de una información escrita, cualquiera sea su contenido. ${ }^{33}$

En cuanto al dicho del oráculo en Sobre la embajada fraudulenta, no es posible analizarlo directamente, ya que es solo referido. No obstante, las dos interpretaciones que propone Demóstenes permiten reconstruir su sentido. Se trataría de un oráculo cuyos símbolos y metáforas están vinculados a la unidad del démos ateniense (Martin: 2009, 208). Por último, al igual que la sospecha lanzada por Aristófanes en Caballeros (818-819) respecto al recitado de oráculos y la división de la polis, Demóstenes tam-

${ }^{31}$ En Herodoto, también puede rastrearse un uso formulaico similar respecto al «decir mántico»:

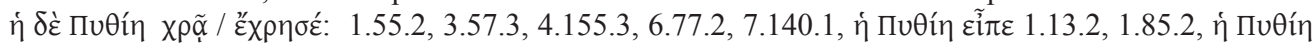
$\lambda \dot{\varepsilon} \gamma \varepsilon l(1.47 .2,1.65 .2,1.67 .3)$.

${ }^{32}$ También en Contra Midias (51-56) se encuentra un uso similar.

${ }^{33}$ Sobre la «documentación escrita del pasado» y su uso en la oratoria, ver Thomas (1989: 83-93), Gavrilov (1997), Sickinger (2002). Sobre religión y oratoria, King (1955). 
bién enfatiza la instrumentalización que hacen los que lideran ( $\pi \rho \circ \varepsilon \sigma \tau \eta \kappa o ́ \tau \omega v) .{ }^{34} \mathrm{De}$ esta manera, el oráculo «citado» y leído en el discurso Sobre la embajada fraudulenta es un documento escrito de persuasión entre otros que, no obstante, también advierte sobre la manipulación en el uso de los oráculos. Si los oráculos escritos contribuían a resolver situaciones particulares de consenso durante el período arcaico y el siglo $v$ a.C., el empleo que hace Demóstenes en el siglo IV a.C. muestra un desuso de su función tradicional posibilitado, en parte, por la mediación escrita.

\section{CONCLUSIÓN}

Tomando la comedia aristofánica como fuente histórica, una fuente de características particulares que refleja distintas prácticas sociales de la Atenas clásica, se intentó reconstruir a partir de Aves la práctica mántica de los oráculos, sus elementos materiales, su técnica y los valores sociales en puja que la constituyeron. El testimonio que ofrece la comedia no es sobre la Atenas clásica «tal cual es/fue», sino que exagera y sobredimensiona con finalidad cómica la realidad para mostrar «cómo» esa realidad podría ser vista - pero sin que sea efectivamente así-. De esta manera, abre un espacio para la proyección utópica («cómo podría ser»), ${ }^{35}$ al mismo tiempo que enfatiza los puntos críticos y sensibles sobre temas de la vida social («cómo sería mejor que fuera o no fuera») ${ }^{36}$ En constraste con el explanandum sobre la crisis de autoridad mántica narrado por Tucídides, el análisis de la escena del cresmólogo intruso en Aves permite observar estos distintos planos de la práctica mántica del oráculo en la Atenas clásica («cómo podría ser vista», «cómo podría ser» y «cómo sería mejor que fuera o no fuera»). La producción y colección escrita de los oráculos aparece así bajo la lupa cómica, mostrando las tensiones que existen sobre su uso - y abuso - social, su autenticidad, su circulación y su monopolio. La comparación con la oratoria de Demóstenes muestra no solo una similitud en el uso escrito, pero también una transformación, un

${ }^{34}$ En Caballeros (v. 812), también se insinúa la instrumentalización política del oráculo a través de la comparación de Paflagonio con Temístocles, fama que puede recuperarse de su biografía hecha por Plutarco (Them. 20.3), ver Pérez Jiménez (1992).

${ }^{35}$ Konstan (1995). Su propuesta consiste en analizar las maneras en que la obra responde a ciertos temas culturales dando forma a las narraciones con las que los atenienses se definían y comprendían a sí mismos. A diferencia de otros críticos de la comedia aristofánica, esto no significa que las obras reflejen [reflection] sin mediación los conflictos sociales. Desde esta perspectiva, el texto literario es el lugar donde se representan dichas tensiones y contradicciones sociales al refractar [refracting] las imágenes dadas por la cultura en una nueva forma. Estas tensiones se manifiestan en el texto, tanto en la construcción de los personajes como en la narración.

${ }^{36}$ Ruffell (2011) centra su propuesta basándose en «la imposibilidad cómica» [comic impossibility] que funcionaría en todos los niveles del discurso cómico, es decir, desde el acto de comunicación ficcional, la construcción de mundos imposibles hasta la absurdidad de las narrativas y los actos individuales. De esta manera, lo imposible sería el principio que mueve todas las comedias. A diferencia de otros géneros, en los que también existen mecanismos realistas de ficcionalidad y teatralidad, el uso radical de estos mismos mecanismos empleados - o sea, antirrealista - en la comedia antigua permite, por un lado, su desplazamiento y la crítica que esto conlleva, al mismo tiempo que politiza el acto de comunicación teatral y la situación de audiencia. 
desuso/re-uso: la pérdida de un sentido decisivo por uno aleccionador. Si durante la Guerra del Peloponeso hubo una superproducción de oráculos y, en consecuencia, una circulación irrestricta y excesiva, no fue solo por el estado de incertidumbre creciente sobre el futuro, sino también por la falta de control en la producción escrita de informaciones oraculares. No solo circulaban oráculos oralmente, sino también colecciones o papiros que les daban «otro» tipo de autenticidad. En una cultura de tradición oral la aparición de la escritura provoca trading zones, en este caso, sobre la producción escrita de oráculos. De esta manera, la escena del cresmólogo intruso en Aves explica parte de este funcionamiento socio-técnico que la descripción de la crisis de autoridad mántica hecha por Tucídides no ofrece. La superproducción de oráculos, su consecuente circulación sin control y las sospechas sobre su autenticidad que ello conlleva muestran cómo la crisis de la autoridad mántica no se debe solo a lo irracional o supersticioso de las esperanzas «oscuras», sino que también es consecuencia de la transformación de condiciones socio-técnicas propias de la práctica oracular.

\section{EDICIONES CONSULTADAS}

Butcher, Samuel (ed.) (1903), Demosthenis. Orationes, Oxford.

Dunbar, Nan (ed.) (1998), Aristophanes' Birds, Oxford.

FuHR, Carolus (ed.) (1914), Demosthenis Orationes, I 3, Leipzig.

GiL, Luis (1995), Aristófanes. Comedias. Los Acarnienses. Los Caballeros, Madrid.

GiL, Luis (2011), Aristófanes. Comedias. Las nubes. Las avispas. La paz. Las aves, Madrid.

HudE, Karl (ed.) (1913-25), Thucydides Historiae, Leipzig.

Jones, Henry (ed.) (1900), Thucydides Historiae, Oxford.

MacDowell, Douglas (ed.) (2000), Demosthenes: On the False Embassy (Oration 19), Oxford. Macía Aparicio, Luis (2007), Aristófanes. Las Nubes, Las Avispas, La Paz, Los Pájaros, Madrid. Olson, Douglas (2002), Aristophanes' Acharnians, Oxford.

Rodríguez Adrados, Francisco (1996), Aristófanes. Los Acarnienses. Los Caballeros. Las Tesmoforias. La Asamblea de las Mujeres, Madrid.

Sommerstein, Alan H. (1981), The Comedies of Aristophanes, vol. 2. Knights, Warminster.

\section{BiBLIOGRAFÍA CITADA}

ABel, Lionel (1963), Metateather: A new view of dramatic form, Nueva York.

Arrowsmith, William (1973), «Aristophanes’ Birds: The Fantasy Politics of Eros», Arion 1: 119-167.

Assmann, Jan (2000), Das kulturelle Gedächtnis. Schrift, Erinnerung und politische Identität in frühen Hochkulturen, München.

Bain, Daniel (1977), Actors and Audience: A Study of Asides and Related Conventions in Greek Drama, Oxford. 
BARKER, Elton (2006), «Paging the oracle: interpretation, identity and performance in Herodotus' History», Greece \& Rome 53 1: 1-28.

Barrett, James (1998), «Pentheus and the Spectator in Euripides’ Bacchae», AJPh 1193.

Baumgarten, Roland (1998), Heiliges Wort und Heilige Schrift bei den Griechen : Hieroi Logoi und verwandte Erscheinungen, Tübingen.

BELFIORE, Elizabeth (2003), «Tragédie, thumos, et plaisir esthétique», Les Études philosophiques, No. 4, La Poétique d'Aristote: Lectures morales et politiques de la tragédie.

BERRA, Aurélien (2008), Théorie et pratique de l'énigme en Grèce ancienne, Paris.

BETA, Simone (2004), Il linguaggio nelle commedie di Aristofane: parola positiva e parola negativa nella commedia antica, Roma.

BIERL, Anton (1991), Dionysos und die griechische Tragödie: politische und «metatheatralische» Aspekte im Text, Tübingen: Narr.

BIJker, Wiebe et al (1990), The Social Construction of Technological Systems, Cambridge.

Bowden, Hugh (2005), Classical Athens and the Delphic oracle: divination and democracy, Cambridge.

Brodersen, K. (2001), Prognosis: Studien zur Funktion von Zukunftsvorhersagen in Literatur und Geschichte seit der Antike, Münster.

- (2001), Gebet und Fluch; Zeichen und Traum: Aspekte religiöser Kommunikation in der Antike, München.

Buis, Emiliano (2009), «Fragmentos de un discurso jurídico: la descontextualización del léxico judicial y su eficacia cómica en Comensales de Aristófanes», Emérita 77: 79-108.

- (2011), «Enacting Law on Stage: Time, Comic Rhetoric and Legislative Language in Aristophanes' Acharnians (vv. 676-718)», Revue Internationale des Droits de l'Antiquité (RIDA) 58 .

- (2013), «The Lord of the Wings: Political Leadership and the Rhetorical Manipulation of Athenian Law in Aristophanes' Birds», CHS Research Bulletin: 1-17.

Chaniotis, A. (ed.) (2009), Applied Classics. Comparisons, Constructus, Controversies, Stuttgart. Croiset, Maurice (1906), Aristophane et les partis Athénes, Paris.

Dillery, John (2005), «Chresmologues and Manteis: Independent Diviners and the Problem of Authority», en JohnSTON - STRUCK (2005: 167-232).

Dobrov, Gregory (ed.) (1995), Beyond Aristophanes: Transition and Diversity in Greek Comedy, Atlanta.

- (ed.) (1997), The City as Comedy: Society and Representation in Athenian Drama. Chapel Hill.

Ehrenberg, Victor (1962), The People of Aristophanes: A Sociology of Old Attic Comedy, New York.

EIdinOw, Esther (2013), «Oracular Consultation, Fate, and the Concept of the Individual», en ROSENBERGER (2013).

Foley, Helene (2006), "Generic boundaries in late Fifth-Century Athens», en Revermann WiLSON (2006: 16-36).

Foley, Helene (ed.) (1981), Reflections of Women in Antiquity, New York and London.

ForTIER, Mark (1997), Theory/Theatre: An Introduction, London.

GAGARIN, Michael (2007), «Background and origins: Oratory and rhetoric before the Sophists», en WORTHINGTON (2007 : 27-36).

GAVRILOv, Alexander (1997), «Techniques of Reading in Classical Antiquity», CQ 47 1: 56-73. 
Gentili, Bruno (1979), Theatrical Performance in the Ancient World: Hellenistic \& Early Roman Theatre, Oxford.

GiL, Luis (1996), Aristófanes, Madrid.

Goldberg, Simon (1980), The Making of Menandrian Comedy, London.

Gomme, Arnold (1938), «Aristophanes and politics», CR 52: 97-109.

Harris, William (1989), Ancient Literacy, Cambridge.

HAVELOCK, Eric (1996), La musa aprende a escribir, Barcelona.

Heath, Malcolm (1987 [2007]), Political Comedy in Aristophanes, Göttingen (Hypomnemata 87).

- (1997), «Aristophanes and the discourse of politics» en Dobrov (1995: 230-49).

Henderson, Jeffrey (1990), «The demos and the comic competition», en WinKLER - Zeitlin (1990: 271-313).

- (1987), «Older women in Attic Comedy», TAPhA 117: 105-29.

Henrichs, Albert (2003), «Hieroi Logoi and Hierai Bibloi: The (Un)Written Margins of the Sacred in Ancient Greece», CPh $101:$ 207-266.

Hollmann, Alexander (2006), «The Manipulation of Signs in Herodotos’ Histories», TAPhA 135 2: 297-298.

Holtermann, Martin (2004), Der deutsche Aristophanes: die Rezeption eines politischen Dichters im 19. Jahrhundert, Göttingen.

Hornblower, Simon (1992), «The religious dimension to the Peloponnesian war, or, what Thucydides does not tell us», HSCPh 94: 169-197.

Hubbard, Thomas (1991), The Mask of Comedy. Aristophanes and the Intertextual Parabasis, London.

- (2007), «Attic Comedy and the Development of Theoretical Rhetoric», en WORTHINGTON (2007: 490-508).

Hugill, William (1936), Panhellenism in Aristophanes, Chicago.

IRIARTE, Ana (1990), Las redes del enigma. Voces femeninas en el pensamiento griego, Madrid.

Johnston S. \& Struck, P. (eds.) (2005), Mantikê: studies in ancient divination, Boston.

Jordan, B. (1986), «Religion in Thucydides», TAPhA 116:119-147.

Kanngieser, Peter (1817), Die alte komische Bühne in Athen, Breslau.

KINDT, Julia (2001), «Von Schafen und Menschen: Delphische Orakelsprüche und soziale Kontrolle», en BRODERSEN (2001: 25-38).

KING, Daniel (1955), «The Appeal to Religion in Greek Rhetoric», The Classical Journal 50 8: 363-376.

Kitzbichler, Josefine (2014), Poetische Vergegenwärtigung, historische Distanz. Johann Gustav Droysens Aristophanes-Übersetzung (1835/38), Berlin.

Köchly, Hermann. (1857), «Über die Vögel des Aristophanes», Zürich.

Kock, Theodor (1884), «Aristophanes als Dichter und Politiker», Rheinisches Museum für Philologie.

Konstan, David (1995), Greek Comedy and Ideology, New York.

Kraus, Walter (1986), Aristophanes' politische Komödien, Wien.

Kreimer P. - Thomas, H. (2000), Aspectos sociales de la Ciencia y la Tecnología, Berna.

Kwapisz, J.; Petrain, D.; Szymański, M. (Ed.) (2013), The Muse at Play: Riddles and Wordplay in Greek and Latin Poetry. Beiträge zur Altertumskunde, Berlin. 
López FÉrez, Juan Antonio (ed.) (1998), La comedia griega y su influencia en la literatura española, Madrid.

Luz, Christine (2010), Technopaignia: Formspiele in der griechischen Dichtung, Brill.

Marinatos, Nanno (1981), Thucydides and religion, 1981.

MARx, Leo \& Smith, Roe (eds.) (1996), Historia y determinismo tecnológico, Madrid.

Maurizio, Lisa (1997), «Delphic Oracles as Oral Performances: Authenticity and Historical Evidence», CA 16: 308-334.

Mikalson, John (1984), «Religion and the plague in Athens», en Rigsby (1984: 217-225).

Monda, Salvatore (Ed.) (2012), 'Ainigma'e 'griphos' gli antichi e l'oscurità della parola, Pisa.

Morgan, Cathrin (1990), Athletes and Oracles: The Transformation of Olympia and Delphi in the Eighth Century $B C$, Cambridge.

Müller-StrüBIng, Hermann (1873), Aristophanes und die Historische Kritik. Polemische Studien zur Geschichte von Athen in fünften Jahrhundert vor Ch. G., Leipzig.

MuÑoz Llamosas, Virginia (2001), «El plano irracional externo en Tucídides», Gerión 19: 293-311.

Murray, Gilbert (1933), Aristophanes: A Study, Oxford.

O'Hara, Thomas (1991), Thucydides and the irrational, Michigan.

ONG, Walter (1987), Oralidad y escritura. Tecnologías de la palabra, México.

Oost, S. (1975), «Thucydides and the Irrational: Sundry Passages», CPh 70 3: 186-196.

Powell, Charles (1979), «Religion and the sicilian expedition», Historia 28: 15-31.

Rau, Peter (1967), Paratragodia: Untersuchung einer komischen Form des Aristophanes, Munich.

REBENICH, Stefan (2009), «Wilhelm von Humboldt — oder: Die Entstehung des Bürgetums aus dem Gesite der Antike», en Chaniotis (2009: 97-118).

Revermann \& Wilson (eds.) (2006), Performance, Iconography, Reception. Studies in Honour of Oliver Taplin, London.

Revermann, Martin \& Wilson, Peter (eds.) (2006), Performance, Iconography, Reception. Studies in Honour of Oliver Taplin, London.

Rigsby, K. J. (ed.) (1984), Studies presented to Sterling Dow on his eightieth birthday, Durham: Duke University.

Ringer, Martin (1998), Electra and the Empty Urn: Metatheater and Role Playing in Sophocles, California.

Rosenberg, Nathan (1982), Inside the Black Box: Technology and Economics, New York.

Rosenberger, Veit (2001a), Griechische Orakel. Eine Kulturgeschichte, Stuttgart.

- (2001b), «Zeichen göttlichen Zornes. Eine mediengeschichtliche Untersuchung des römischen Prodigienwesens», en BRODERSEN (2001: 69-88).

- (ed.) (2013), Oracles in the Ancient World: Religious Options and the Individual, Stuttgart. Rosenmeyer, Thomas (2002), “'Metatheater': An Essay on Overload», Arion 10 2: 87-119.

RufFell, Ian (2006), «Audience and Emotion in the Reception of Greek Drama», en ReverMANN - WiLSON (2006: 37-58).

Ruffell, Ian (2011), Politics and Anti-Realism in Athenian Old Comedy, Oxford.

SCHLEGEL, Friedrich (1794), «Vom ästhetischen Werte der griechischen Komödie», Kritische Schriften und Fragmente I: 9-15, [ed. Behler], Paderborn: Schöningh, 1968.

Schlosser, J. G. (1783), Die Frösche. Ein Lustspiel aus dem Griechischen des Aristophanes, Basel. 
Schwarze, Joachim (1971), Die Beurteilung des Pericles durch die attische Komödie und ihre historische und historiographische Bedeutung, München.

Segal, Eric (1996), Oxford readings in Aristophanes, Oxford.

Sidwell, Keith (2009), Aristophanes the Democrat: The Politics of Satirical Comedy during the Peloponnesian War, Cambridge.

SLATER, Niall (1996), «Literacy and Old Comedy», Voice Into Text: 99-114.

- (2002), Spectator Politics. Metatheatre and Performance in Aristophanes, Philadelphia.

Sмiтн, Nicolas (1989), «Diviners and Divination in Aristophanic Comedy», Classical Antiquity 8 1: 140-158.

Sokolowski, Franciszek (1954), «Fees and Taxes in the Greek Cults», The Harvard Theological Review 47 III: 153-164.

Sommerstein, Alan (1998), «The theater audience and the demos», en LóPEz FÉrez, Juan (ed.), La comedia griega y su influencia en la literatura española, Madrid.

SPIELVöGEL, Jörg (2001), Wirtschaft und Geld bei Aristophanes: Untersuchungen zu den ökonomischen Bedingungen in Athen im Übergang vom 5. zum 4. Jh. v. Chr., Frankfurt.

Ste Croix, Geoffrey de (1972 [1996]), «The Political Outlook of Aristophanes», en SegaL (1996: 42-64).

SuÁrez de la Torre, Emilio (1998), «Observaciones sobre la presencia de la mántica en la Comedia griega», en LÓPEZ FÉrez (1998: 177-201).

Svenbro, Jesper (1993), Phrasikleia: an anthropology of reading in ancient Greece, London.

TAAfFe, Lauren (1994), Aristophanes and Women, London.

TAPLin, Oliver (1978), Greek Tragedy in Action, Oxford.

- (1986), «Fifth-Century Tragedy and Comedy: A Synkrisis», The Journal of Hellenic Studies 106: $163-174$.

Thomas, Hernán (2000), «Tecnología y Sociedad», en Kreimer - Thomas, (2000: 148-175).

Thomas, Rosalind (1989), Oral tradition and written record in classical Athens, Cambridge.

VAN DıJ,, G.-J. (1997), Ainoi, logoi, muthoi. Fables in archaic, classical, and hellenistic Greek literature. With a study of the theory and terminology of the genre, Leyde.

Walsh, Phillip (2009), 'A study in reception: the British debates over Aristophanes' Politics and Influence,” Classical Receptions Journal 1(1): 55-72.

White, Lynn (1990), Tecnología medieval y cambio Social, Barcelona.

Winkler, J. \& Zeitlin, F. (eds.) 1990), Nothing to Do with Dionysos? Athenian Drama in its Social Context, Princeton.

Worthington, I. (ed.) (2007), A Companion to Greek Rhetoric, Oxford.

Yunis, Harvey (2003), Written texts and the rise of literate culture in ancient Greece, Cambridge. 